\title{
Experimental study on interaction between simulated sandstone and acidic fluid
}

\author{
Zhang Yongwang ${ }^{1,2 *}$, Zeng Jianhui ${ }^{1,2}$ and Yu Bingsong ${ }^{3}$ \\ ${ }^{1}$ State Key Laboratory of Petroleum Resource and Prospecting, China University of Petroleum, Beijing 102249, China \\ ${ }^{2}$ Basin and Reservoir Research Center, China University of Petroleum, Beijing 102249, China \\ ${ }^{3}$ State Key Laboratory of Geological Processes and Mineral Resources, China University of Geosciences, Beijing 100083, China
}

\begin{abstract}
In order to investigate the controlling mechanism of temperature, fluid and other factors on water-rock interaction in the diagenetic process, we performed a series of simulated experiments on the interaction between two kinds of fluids with different salinity and a composite mineral system (simulated sandstone), which contains albite, K-feldspar and other minerals. The experimental results showed that acidity was the most important factor that affected the dissolution of minerals in the composite mineral system. The lower the $\mathrm{pH}$ value, the more easily the minerals dissolved. At the same $\mathrm{pH}$ value, the dissolution abilities of different acids for various mineral components were also different. Compared to hydrochloric acid (inorganic acid), oxalic acid (organic acid) was more able to dissolve aluminosilicate minerals. However, the dissolution ability of oxalic acid for carbonate minerals was lower than that of hydrochloric acid. In the process of fluid-rock interaction, dissolution of feldspar was relatively complicated. Increase of temperature would accelerate the dissolution of feldspar. Under acidic conditions, albite had a higher dissolution rate than K-feldspar. K-feldspar could dissolve and convert into montmorillonite and kaolinite, while albite could dissolve and convert into kaolinite both at $40^{\circ} \mathrm{C}$ and $80^{\circ} \mathrm{C}$. Presence of organic acid, and decrease of $\mathrm{pH}$ value and water salinity were all favorable for the dissolution of feldspar, but weakened the ability to form clay minerals.
\end{abstract}

Key words: Fluid, simulated sandstone, dissolution, static experiment

\section{Introduction}

Since the 1970 s, people have gradually recognized that the formation of secondary pores in the sandstone reservoirs is one of the key factors affecting the nature of sandstone reservoirs. Over one third of the known sandstone pores at present are secondary pores, which can be regarded as the key reservoir space and permeability in the reservoir beds of many oil and gas fields in the world, and are probably more numerous than primary pores (Xiang et al, 2004). Secondary pores in sandstone reservoirs are controlled by diagenesis (Qiu et al, 1997; Anjos et al, 2000; Dillon et al, 2004). The formation mechanism of secondary pores is closely related to the dissolution of skeleton particles, such as feldspar and carbonate cementation in the burial diagenesis process (Liu and Zhao, 1993; Chen et al, 1999; Shah and Bandyopadhyay, 2005; Li et al, 2005; Ji and Xu, 2007). Therefore, people have made a lot of simulated experiments to study the interaction between fluid and a single mineral, such as feldspar, and to explore the dissolution mechanisms and controlling factors of diagenesis (Wollast and Chou, 1992; Chen et al, 1993; Hellmann, 1994; Shi et al, 1994; Oelkers and Schott, 1995; Xiao et al, 2003; Xiang et al, 2004; Chardon et al, 2006). Research results showed that the dissolution of feldspar is related to its composition and structure, reaction temperature and pressure, and fluid properties. The dissolution of feldspar

*Corresponding author. email: zyw75@126.com

Received July 7, 2008 is controlled by surface reaction and diffusion. Very few experimental studies on sandstone dissolution have been focused on the dissolution characteristics of feldspar and the formation mechanism of secondary pores (Yang et al, 1995; $\mathrm{Ji}$ and $\mathrm{Xu}, 2007)$. We performed simulated experiments on the interaction of fluid and a composite mineral system to learn more about the conversion of the mineral components, the effect of reaction temperature and the nature of fluid upon the water-rock interaction in the diagenetic process, as well as to collect data under different experimental conditions for deeper understanding of the fluid-rock interaction mechanism.

\section{Experimental principle and approach}

\subsection{Experimental principle}

This research used a static mineral immersion method to study the influence of temperature, $\mathrm{pH}$ value, water salinity, and organic acid content on fluid-rock interaction, mainly through the change of fluid composition before and after the reaction. In the simulated experiment, the solid samples are all complex mineral systems containing K-feldspar, albite, quartz, calcite, and other minerals. The compositions of the minerals are similar to those of actual detrital reservoir rocks.

\subsection{Experimental samples}

\subsubsection{Preparation of sandstone samples}

Fresh Yangfang granodiorite was used. By crushing, 
screening, and magnetic separation, mixture samples of $<0.1 \mathrm{~mm}, 0.1-0.25 \mathrm{~mm}, 0.25-0.5 \mathrm{~mm}$ in size that comprise K-feldspar (63\%), albite (10\%), quartz (25\%), and biotite (1\%) were obtained. Then the samples were mixed with $1 \%$ of Fengshan limestone of the same particle size. Finally the samples were cleaned with ultrasonic wave, and dried for use after wet-screening.

Polished sections were analyzed with an electron microprobe and the results for K-feldspar and albite are shown in Table 1.

Table 1 Chemical compositions of K-feldspar and albite samples

\begin{tabular}{|c|c|c|c|c|c|c|}
\hline \multirow{2}{*}{$\begin{array}{l}\text { Oxide } \\
\text { wt } \%\end{array}$} & \multicolumn{3}{|c|}{ K-feldspar } & \multicolumn{3}{|c|}{ Albite } \\
\hline & Yfgr-1 & Yfgr-2 & Yfgr-7 & Yfgr-3 & Yfgr-4 & Yfgr-8 \\
\hline $\mathrm{SiO}_{2}$ & 65.66 & 66.39 & 66.1 & 67.66 & 66.91 & 68.3 \\
\hline $\mathrm{TiO}_{2}$ & 0.02 & 0 & 0.05 & 0.02 & 0.05 & 0 \\
\hline $\mathrm{Al}_{2} \mathrm{O}_{3}$ & 18 & 17.85 & 18.51 & 19.87 & 19.82 & 19.93 \\
\hline $\mathrm{Cr}_{2} \mathrm{O}_{3}$ & 0 & 0.09 & 0 & 0.12 & 0.01 & 0 \\
\hline $\mathrm{FeO}$ & 0.14 & 0.05 & 0.07 & 0.26 & 0.12 & 0.19 \\
\hline $\mathrm{MgO}$ & 0 & 0 & 0 & 0 & 0.06 & 0 \\
\hline $\mathrm{MnO}$ & 0.07 & 0.04 & 0.08 & 0 & 0 & 0.15 \\
\hline $\mathrm{CaO}$ & 0.12 & 0.05 & 0.28 & 1.01 & 1.09 & 0.55 \\
\hline $\mathrm{NiO}$ & 0 & 0.18 & 0.04 & 0.04 & 0 & 0.24 \\
\hline $\mathrm{CoO}$ & 0 & 0.13 & 0 & 0 & 0 & 0.05 \\
\hline $\mathrm{Na}_{2} \mathrm{O}$ & 1.5 & 0.73 & 1.34 & 11.12 & 10.77 & 10.94 \\
\hline $\mathrm{K}_{2} \mathrm{O}$ & 14.43 & 13.47 & 13.59 & 0.09 & 0.43 & 0.16 \\
\hline $\mathrm{P}_{2} \mathrm{O}_{5}$ & 0 & 0.1 & 0 & 0 & 0 & 0 \\
\hline Total & 99.94 & 99.08 & 100.06 & 100.18 & 99.25 & 100.51 \\
\hline
\end{tabular}

\subsubsection{Preparation of water samples}

Two types of water samples were used in the experiment: distilled water and Dongying simulated water. Dongying simulated water was prepared according to the chemical composition of ancient salt water in the Dongying Depression, Bohai Bay Basin, as shown in Table 2. According to the experiment requirement, a certain amount of distilled water or simulated Dongying water was mixed with oxalic

Table 2 Chemical compositions of experimental water

\begin{tabular}{c|c|c|c|c|c|c}
\hline \multirow{2}{*}{ Water type } & \multicolumn{5}{|c|}{ Ion content, $\mathrm{mg} / \mathrm{L}$} & \multirow{2}{*}{$\begin{array}{c}\text { Total salinity, } \\
\mathrm{mg} / \mathrm{L}\end{array}$} \\
\cline { 2 - 6 } & $\mathrm{K}$ & $\mathrm{Na}$ & $\mathrm{Mg}$ & $\mathrm{Cl}$ & $\mathrm{SO}_{4}$ & \\
\hline $\begin{array}{c}\text { Dongying } \\
\text { simulated water }\end{array}$ & 81.3 & 2239.6 & 245.5 & 3846.9 & 537.7 & 6950.9 \\
\hline
\end{tabular}

acid, and the $\mathrm{pH}$ value was adjusted by adding hydrochloric acid or sodium hydroxide.

\subsection{Experimental approach}

$1000 \mathrm{mg}$ of solid sample was put into a $250 \mathrm{~mL}$ conical flask with stopper, and $36 \mathrm{~mL}$ experimental water was added. The sealed flask was put into a constant temperature incubator first for heating for 15 minutes, and then the reaction duration was recorded.

After the step above, the flask was cooled by flushing with tap water. The solid was filtered from the liquid with a $0.45 \mu \mathrm{m}$ membrane filter and the $\mathrm{pH}$ value and the chemical composition of the liquid were measured. The $\mathrm{pH}$ value was measured with an ORION720 pH meter with an accuracy of 0.01 . $\mathrm{Ca}, \mathrm{Mg}, \mathrm{Fe}, \mathrm{Si}, \mathrm{Ba}$ in the solution were measured by ICP-AES, with an accuracy of $0.01 \mu \mathrm{g} / \mathrm{mL}$. The K and Na components were measured by WGH-I flame photometer manufactured in Shanghai with an accuracy of $0.1 \mu \mathrm{g} / \mathrm{mL}$ and a measuring range of $0-35 \mu \mathrm{g} / \mathrm{mL}$. Samples beyond the above range were diluted appropriately before final measurement. The static experimental conditions of each group are shown in Table 3.

Table 3 Static experimental scheme

\begin{tabular}{|c|c|c|c|c|c|c|}
\hline $\begin{array}{l}\text { Serial } \\
\text { number }\end{array}$ & Numbering & $\begin{array}{c}\text { Temperature } \\
{ }^{\circ} \mathrm{C}\end{array}$ & $\mathrm{pH}$ & $\begin{array}{c}\text { Oxalic acid } \\
\text { content } \\
\mathrm{mmol} / \mathrm{L}\end{array}$ & $\begin{array}{l}\text { Particle } \\
\text { size, mm }\end{array}$ & $\begin{array}{l}\text { Water } \\
\text { types }\end{array}$ \\
\hline 1 & RCA-1 & 40 & 4 & 5 & $0.1-0.25$ & $\begin{array}{l}\text { Distilled } \\
\text { water }\end{array}$ \\
\hline 2 & TCA-1 & 40 & 8 & 5 & $0.25-0.5$ & $\begin{array}{l}\text { Dongying } \\
\text { simulated } \\
\text { water }\end{array}$ \\
\hline 3 & RCB-1 & 80 & 4 & 5 & $<0.1$ & $\begin{array}{l}\text { Distilled } \\
\text { water }\end{array}$ \\
\hline 4 & TCB-1 & 80 & 6 & 5 & $0.1-0.25$ & $\begin{array}{l}\text { Dongying } \\
\text { simulated } \\
\text { water }\end{array}$ \\
\hline 5 & RB-1 & 80 & 2 & 5 & $<0.1$ & $\begin{array}{l}\text { Dongying } \\
\text { simulated } \\
\text { water }\end{array}$ \\
\hline 6 & RB-2 & 80 & 4 & 0 & $<0.1$ & $\begin{array}{l}\text { Distilled } \\
\text { water }\end{array}$ \\
\hline 7 & RB-3 & 80 & 2 & 0 & $<0.1$ & $\begin{array}{l}\text { Dongying } \\
\text { simulated } \\
\text { water }\end{array}$ \\
\hline 8 & RB-4 & 80 & 2 & 5 & $<0.1$ & $\begin{array}{l}\text { Distilled } \\
\text { water }\end{array}$ \\
\hline 9 & RB-5 & 80 & 4 & 0 & $<0.1$ & $\begin{array}{l}\text { Dongying } \\
\text { simulated } \\
\text { water }\end{array}$ \\
\hline 10 & TB-2 & 80 & 7 & 5 & $0.1-0.25$ & $\begin{array}{l}\text { Dongying } \\
\text { simulated } \\
\text { water }\end{array}$ \\
\hline 11 & TB-3 & 80 & 4 & 5 & $0.1-0.25$ & $\begin{array}{l}\text { Dongying } \\
\text { simulated } \\
\text { water }\end{array}$ \\
\hline
\end{tabular}




\section{Experimental results and discussions}

\subsection{Interaction between acidic solution prepared from distilled water and the composite mineral system}

Fig. 1 illustrates the change of concentration of $\mathrm{Al}, \mathrm{Ca}, \mathrm{K}$, $\mathrm{Mg}, \mathrm{Na}$, and $\mathrm{Si}$ in the solution with the reaction duration in the interaction process between acidic solution prepared from distilled water and composite mineral system. Fig. 1 indicates the following:

1) During the experiment, the oxalic acid solution of $\mathrm{pH}=2$ favored the dissolution of $\mathrm{Al}$ in the composite mineral system and the concentration of $\mathrm{Al}$ in the solution increased rapidly with the reaction duration, while the other kinds of solutions had relatively poor ability of dissolving $\mathrm{Al}$ in the composite mineral system.

2) The oxalic acid solution of $\mathrm{pH}=2$ had the strongest ability of dissolving $\mathrm{Ca}$ in the composite mineral system. The concentration of $\mathrm{Ca}$ in the solution increased rapidly with the reaction duration. The solution without oxalic acid of $\mathrm{pH}=4$ ranked the second in dissolving $\mathrm{Ca}$, and the dissolved amount of $\mathrm{Ca}$ increased little with increasing reaction duration and approached a balance. Oxalic acid solution of $\mathrm{pH}=4$ had relatively poor ability of dissolving Ca both at $80^{\circ} \mathrm{C}$ and $40^{\circ} \mathrm{C}$.

3) The solubility of $\mathrm{K}$ in oxalic acid solution of $\mathrm{pH}=2$ gradually increased with increasing reaction duration, and the dissolved amount was the most of all experimental runs. Oxalic acid solution of $\mathrm{pH}=4$ at $80^{\circ} \mathrm{C}$ and $40^{\circ} \mathrm{C}$ had a similar dissolution trend for $\mathrm{K}$. It is noticeable that for the reaction duration from 50 hours to 200 hours, the dissolved amount of $\mathrm{K}$ changed greatly. From 50 hours to 100 hours, the dissolved amount of $\mathrm{K}$ increased rapidly and reached a maximum, whereas from 100 hours to 200 hours, the dissolved amount of $\mathrm{K}$ decreased rapidly. Thereafter, the dissolved amount of $\mathrm{K}$ increased slowly again with increasing reaction duration.

4) The oxalic acid solution of $\mathrm{pH}=2$ had the strongest ability of dissolving $\mathrm{Mg}$ in the composite mineral system. The concentration of $\mathrm{Mg}$ in the solution increased rapidly with the reaction duration. As for other solutions, the trends of dissolved amount of $\mathrm{Mg}$ were roughly similar. However, the dissolved amounts were different. Oxalic acid solution of $\mathrm{pH}=4$ at $40^{\circ} \mathrm{C}$ and $80^{\circ} \mathrm{C}$ also had strong ability of dissolving $\mathrm{Mg}$ with a slight difference, while the solution without oxalic acid of $\mathrm{pH}=4$ had the weakest dissolution ability.

5) Eliminating the initial concentration of $\mathrm{Na}$ in all solutions before reaction, it was found that the $\mathrm{pH}=2$ oxalic acid solution had the strongest ability of dissolving $\mathrm{Na}$ in the composite mineral system. The other solutions had basically similar ability of dissolving $\mathrm{Na}$.

6) The dissolution trend of $\mathrm{pH}=2$ oxalic acid solution for $\mathrm{Si}$ in the composite mineral system was almost the same as that for Al. However, the dissolved amount of Si was larger than that of $\mathrm{Al}$, and far larger than that of $\mathrm{Si}$ in other three solutions. Throughout the reaction, the change of the dissolved amount of Si was roughly the same among the three solutions. However, it was noticeable that oxalic acid solution of $\mathrm{pH}=4$ dissolved the smallest $\mathrm{Si}$ at $40^{\circ} \mathrm{C}$, and the dissolved amount was smaller than that in the solution without oxalic acid of $\mathrm{pH}=4$ at the reaction temperature of $80^{\circ} \mathrm{C}$.

The above experimental results showed that:

1) Although the calcite content in the composite mineral system was very low, the dissolution rate of $\mathrm{Ca}$ was higher than those of $\mathrm{Si}, \mathrm{A} 1, \mathrm{~K}$, and $\mathrm{Na}$. This undoubtedly proved that the solubility of calcite was higher than various aluminosilicate minerals.

2 ) In the composite mineral system after dissolution, the absolute content of K-feldspar was around $63 \%$, and the albite content was about $10 \%$. Nevertheless, in the whole experiment, the dissolved amount of $\mathrm{Na}$ was larger than that of $\mathrm{K}$, and the $\mathrm{Na} / \mathrm{K}$ ratio was larger than the ratio of albite and $\mathrm{K}$-feldspar content in the original samples, which showed that albite dissolved more readily than $\mathrm{K}$-feldspar. This conclusion agrees with the result of the experiment by Huang et al (1995) who used perthite as the dissolution sample; i.e., the dissolution rate of albite is higher than that of $\mathrm{K}$-feldspar.

3) The acidity of solution was the most important factor in dissolution of minerals in the composite mineral system. The lower the $\mathrm{pH}$ value, the stronger the dissolution ability. At a strong acidity $(\mathrm{pH}=2)$, the solution had the strongest dissolution ability other than $\mathrm{Na}$, and the cations in the solution increased rapidly with the reaction duration. The other solutions had relatively poor dissolution ability for cations in composite mineral system.

4) When the $\mathrm{pH}$ value was the same, different types of acids had different dissolution ability for various mineral components. Oxalic acid had stronger dissolution ability for $\mathrm{Al}$ and $\mathrm{Mg}$ in the composite mineral system. Other acids (mainly hydrochloric acid) had stronger dissolution ability for $\mathrm{Ca}$ in the composite mineral system. Except some particular reaction durations, oxalic acid and hydrochloric acid showed similar dissolution ability for $\mathrm{K}$ and Si. During the whole reaction duration, oxalic acid and hydrochloric acid showed almost the same dissolution ability for $\mathrm{Na}$. Therefore, oxalic acid was more able to dissolve aluminosilicates than hydrochloride acid, but had weaker dissolution ability for carbonates compared with hydrochloride acid. This was probably because oxalic acid could easily form a calcium oxalate precipitate with $\mathrm{Ca}^{2+}$, which would obstruct further reaction.

5) Except $\mathrm{Ca}$, the oxalic acid solution of $\mathrm{pH}=4$ at 80 ${ }^{\circ} \mathrm{C}$ had higher dissolution ability for $\mathrm{Al}, \mathrm{K}, \mathrm{Mg}, \mathrm{Na}$, and $\mathrm{Si}$ in the composite mineral system than that at $40^{\circ} \mathrm{C}$. Therefore, a higher reaction temperature was advantageous to aluminosilicate dissolution in oxalic acid solution but disadvantageous to carbonate dissolution, because the ionization ability of oxalic acid was enhanced with the increase of temperature, oxalic acid could provide more $\mathrm{H}^{+}$ and oxalate for complexing metal elements, which improved the dissolution of aluminosilicate.

\subsection{Interaction of Dongying simulated water and composite mineral system}

(1) The comparison of reaction results of Dongying simulated water-composite mineral system with an experimental duration of 1,000 hours between the solution containing oxalic acid $(5 \mathrm{mmol} / \mathrm{L})$ and the solution without 

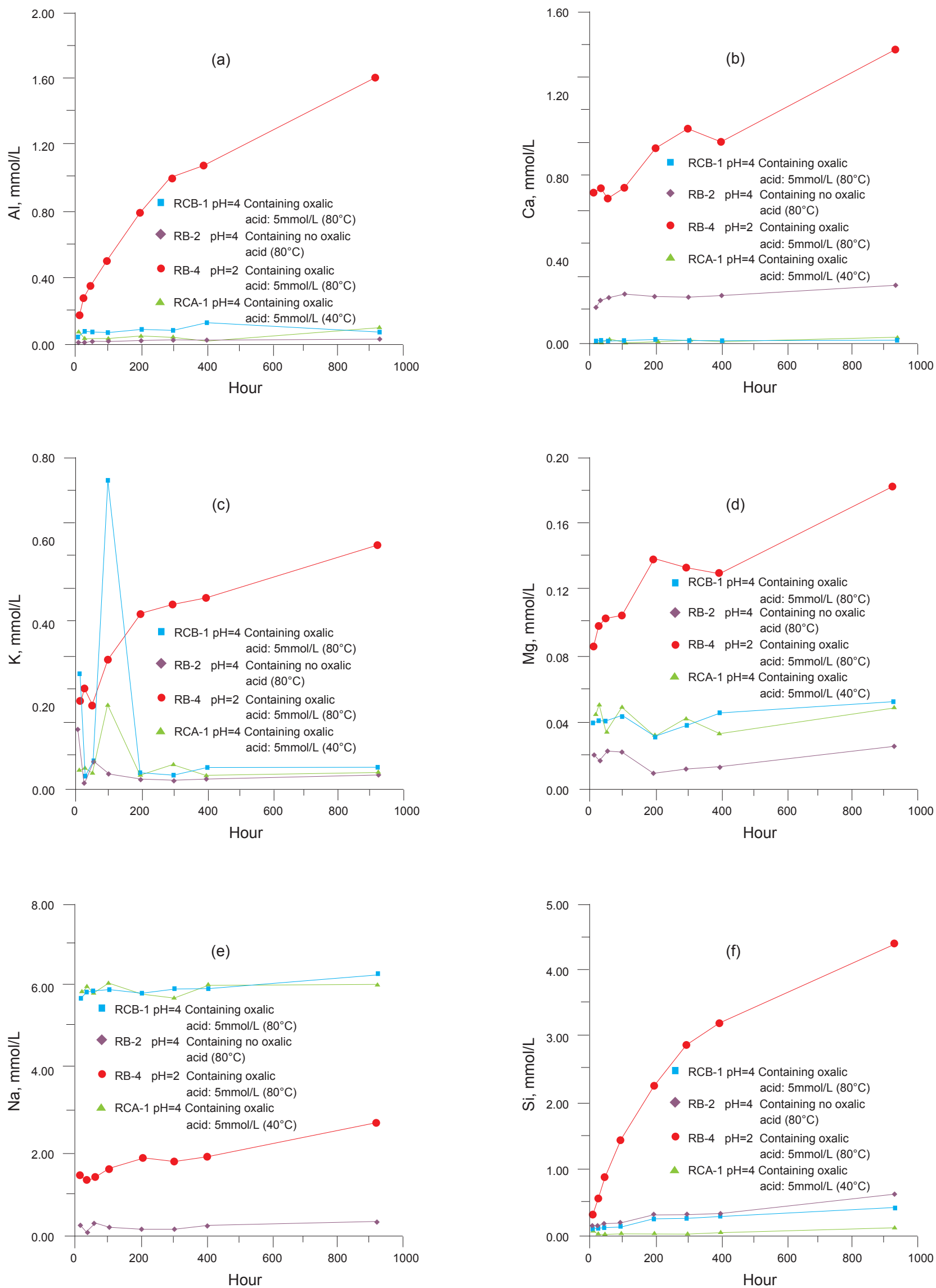

Fig. 1 Concentration change of $\mathrm{Al}, \mathrm{Ca}, \mathrm{K}, \mathrm{Mg}, \mathrm{Na}$, and $\mathrm{Si}$ in the reaction process between composite mineral system and acidic solution prepared from distilled water 
oxalic acid is as follows (Fig. 2(a) and (b)):

When Dongying simulated water contained oxalic acid, various chemical components were transferred from solid phase (minerals) to liquid phase (Dongying simulated water), which meant that dissolution was the major reaction. Only when $\mathrm{pH}=7$, a very small amount of $\mathrm{Mg}, \mathrm{Fe}$, and $\mathrm{Al}$ were transferred from liquid phase to solid phase; that is to say, precipitation took place. When there was no oxalic acid and $\mathrm{pH}=4, \mathrm{Mg}, \mathrm{Fe}$, and $\mathrm{Al}$ were transferred from liquid phase to solid phase, and the precipitation amount of $\mathrm{Mg}$ was the largest.

Dongying simulated water of $\mathrm{pH}=2$ containing oxalic acid had the strongest ability of dissolving various mineral components. Dongying simulated water of $\mathrm{pH}=6$ ranked the second. When there was no oxalic acid, Dongying simulated water of $\mathrm{pH}=2$ had the strongest dissolution ability.

(2) Comparing the effect of oxalic acid on the dissolution of the composite mineral system between $\mathrm{pH}=2$ and $\mathrm{pH}=4$, we found that:

When $\mathrm{pH}=2$, Dongying simulated water with oxalic acid had stronger dissolution ability for various mineral components than that without oxalic acid. However, the change of the dissolved amount of various chemical components was almost the same. This indicated that when $\mathrm{pH}=2$, the differences in the type of acidic medium only affected the dissolved amount and had no obvious effect on the trend of dissolution/precipitation of various mineral components (Fig. 2(c)).

When $\mathrm{pH}=4$, the dissolution ability and reaction results of Dongying simulated water with and without oxalic acid differed greatly. Dongying simulated water with oxalic acid mainly caused the dissolution of various mineral components that were transferred from solid phase to liquid phase. However, Dongying simulated water without oxalic acid caused precipitation. At this time, the dissolved amounts of $\mathrm{Ca}$ and $\mathrm{Si}$ were much higher than those in Dongying simulated water with oxalic acid (Fig. 2(d)). Therefore, when $\mathrm{pH}=4$, the acidic medium not only affected the dissolved amount of mineral components, but also had a major influence on the tendency of dissolution/precipitation. (a)

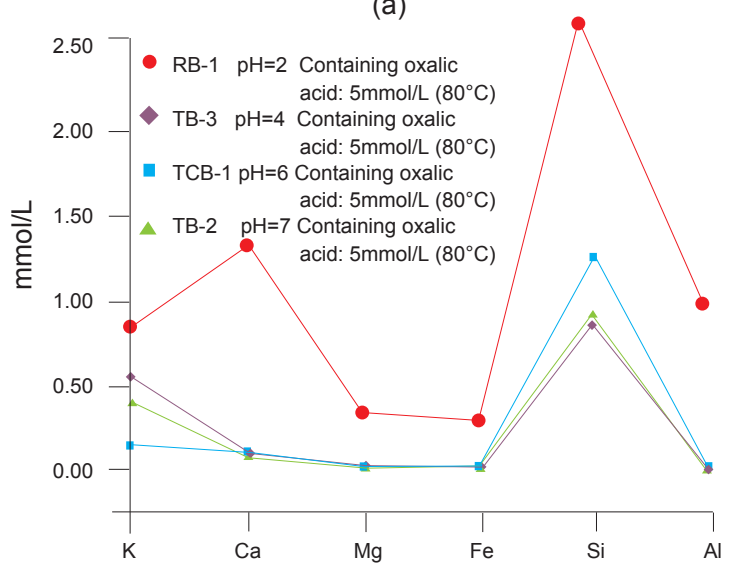

(c)

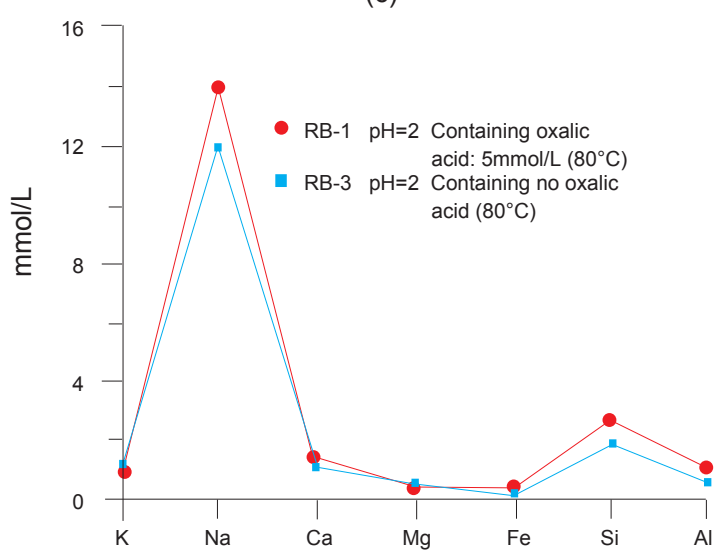

(b)

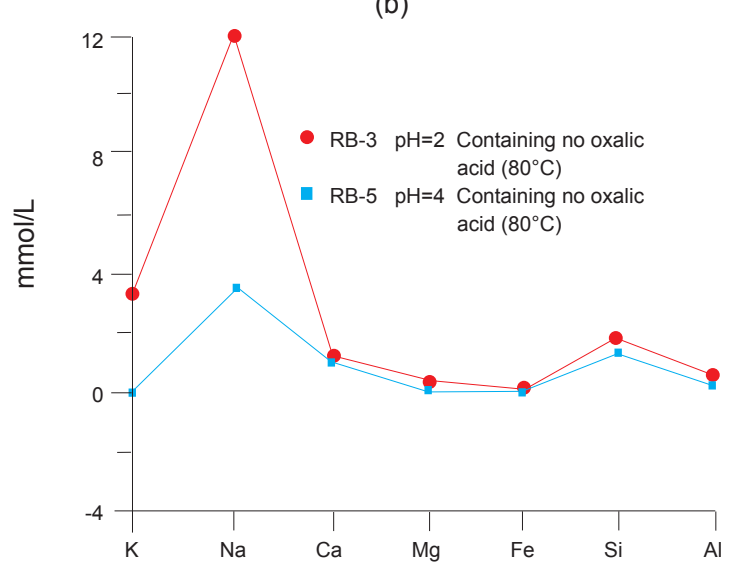

(d)

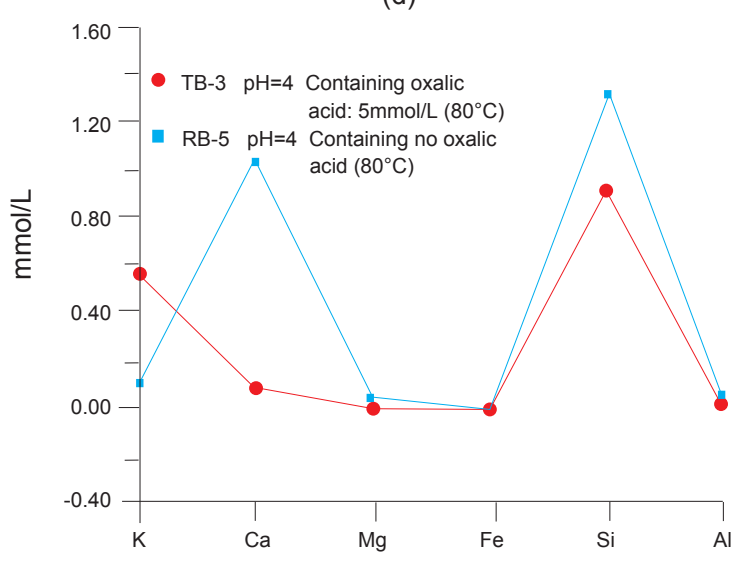

Fig. 2 Dissolved amount of various components of composite mineral system in Dongying simulated water containing different acidic medium 
Through simulated experiments of the interaction between distilled water or Dongying simulated water and composite mineral system, we can conclude that the influence of water salinity on the solubility of various mineral components was different at different $\mathrm{pH}$ values. When $\mathrm{pH}=2, \mathrm{Ca}, \mathrm{Si}$, and $\mathrm{Al}$ were more easily dissolved in distilled water than in Dongying simulated water, but Dongying simulated water

(a)

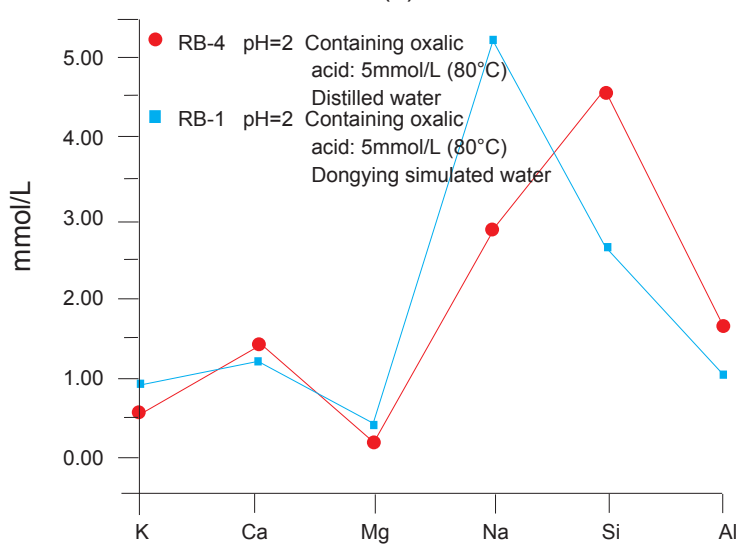

was more able to dissolve $\mathrm{Na}$ in the composite mineral system than distilled water (Fig. 3(a)). Dongying simulated water of $\mathrm{pH}=4$ had higher dissolution ability for $\mathrm{K}$ and $\mathrm{Si}$ in the composite mineral system than distilled water (Fig. 3(b)). In conclusion, the dissolution ability of the fluid for the composite mineral system would become weaker with increasing water salinity.

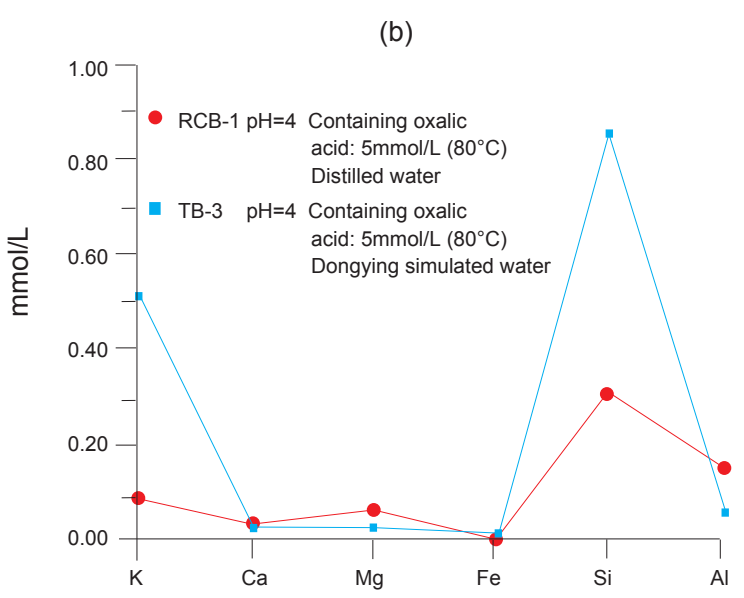

Fig. 3 Influence of salinity on dissolved amount of various components in composite mineral system at different $\mathrm{pH}$ values

\subsection{Controlling factors of feldspar dissolution}

In the process of fluid-rock interaction, the dissolution of feldspar is relatively complicated. There are many factors affecting the dissolution and conversion of feldspar, including its composition and structure, temperature and pressure of reaction, fluid $\mathrm{pH}$ value, and types and contents of organic acids. Research and discussions on various factors of feldspar dissolution and conversion under experimental conditions are of great significance for the study of dissolution mechanism of feldspar and development of secondary pores in the process of diagenesis.

\subsubsection{Influence of temperature on feldspar dissolution}

The result of thermodynamic calculation shows that the stable area of intermediates for feldspar dissolution varies at different temperatures. With respect to $\mathrm{K}$-feldspar, the stable area of montmorillonite enlarges significantly at $40^{\circ} \mathrm{C}$ compared to that at $80^{\circ} \mathrm{C}$ (Fig. 4(a) and (b)). With respect to albite, the stable area of montmorillonite enlarges slightly at $40^{\circ} \mathrm{C}$ compared to that at $80^{\circ} \mathrm{C}$. By comparison of various minerals, the stable area of secondary montmorillonite from albite dissolution is much smaller than that of $\mathrm{K}$-feldspar.
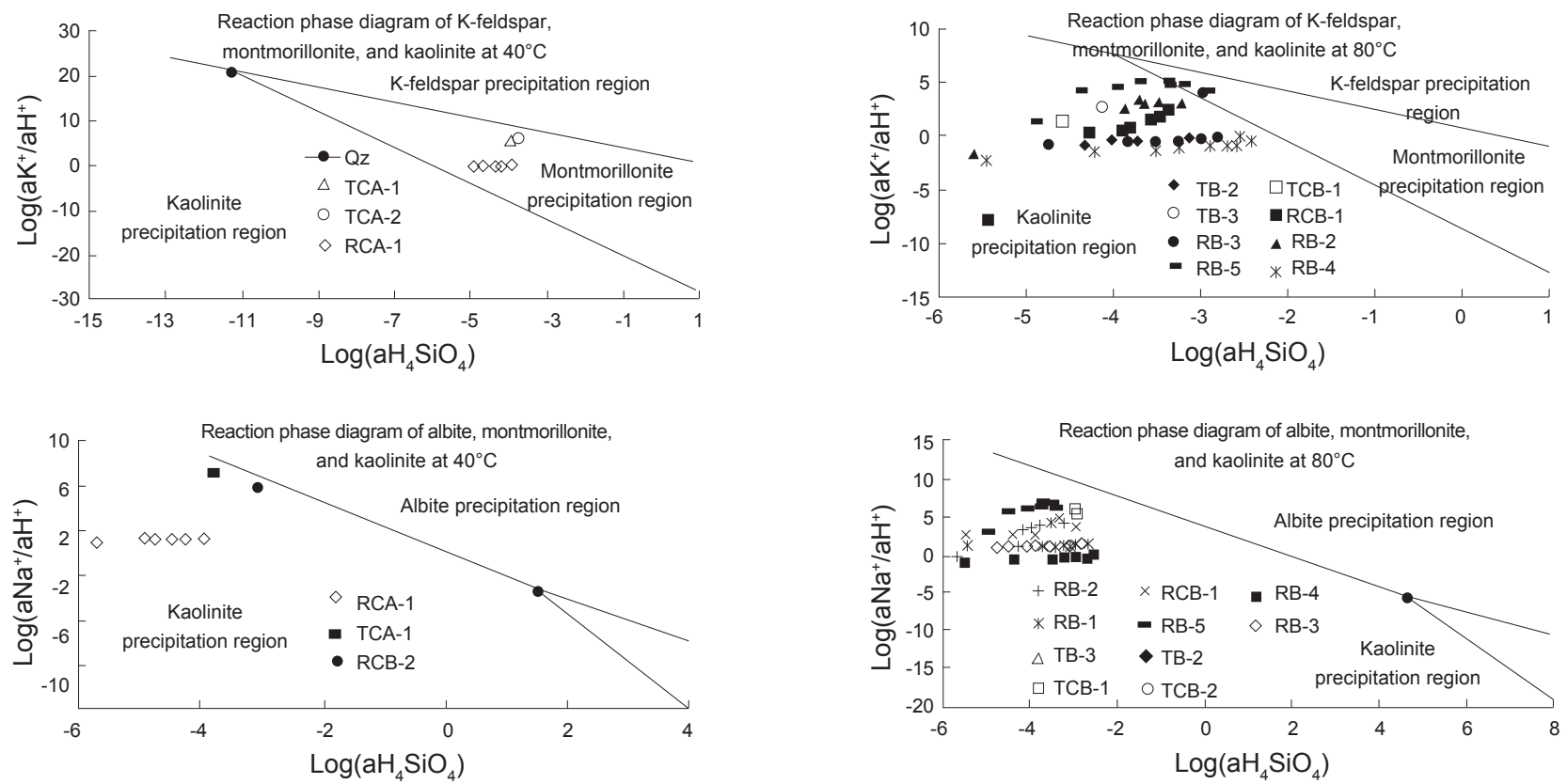

Fig. 4 Reaction phase diagram of $\mathrm{K}$-feldspar (albite)-montmorillonite-kaolinite at $40^{\circ} \mathrm{C}$ and $80^{\circ} \mathrm{C}(\mathrm{Brantley,}, 1992)$ 
That is to say, $\mathrm{K}$-feldspar dissolves more easily and converts into montmorillonite at $40^{\circ} \mathrm{C}$, and $\mathrm{K}$-feldspar dissolves more easily and converts into kaolinite at $80^{\circ} \mathrm{C}$. However, it is difficult for albite to be decomposed and convert into montmorillonite whether the temperature is high or low (Fig. 4(c) and (d)).

The simulated experimental results show that the decomposition intermediates of $\mathrm{K}$-feldspar were all distributed in montmorillonite region at $40^{\circ} \mathrm{C}$, and were distributed in kaolinite and montmorillonite regions, mostly in kaolinite region at $80^{\circ} \mathrm{C}$. The decomposition intermediates of albite were distributed in kaolinite region whether the temperature was high or low (Fig. 4).

(a)

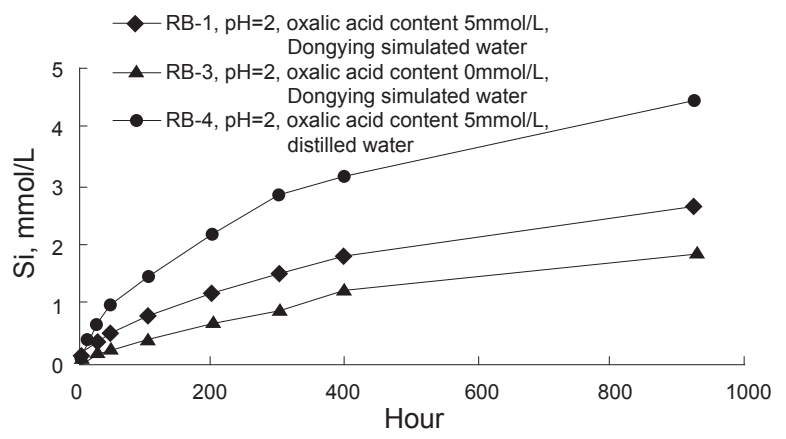

(c)

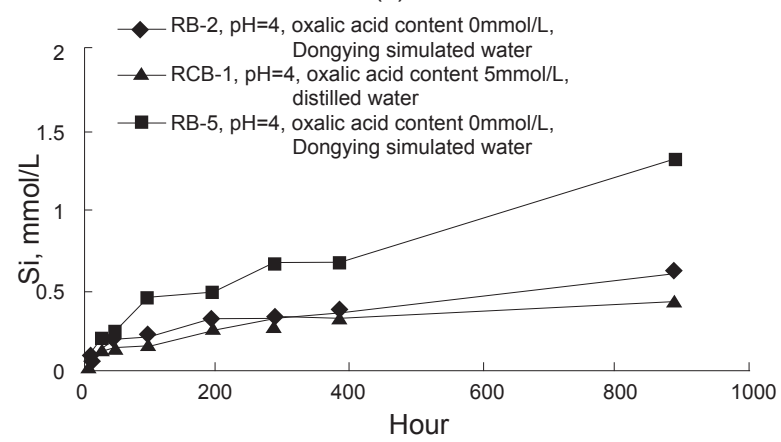

\subsubsection{Influence of organic acids on feldspar dissolution}

The experimental results of the solution with $5 \mathrm{mmol} / \mathrm{L}$ oxalic acid and without oxalic acid showed changes in $\mathrm{Si}$ and $\mathrm{Al}$ contents over time. $\mathrm{Si}$ and $\mathrm{Al}$ contents increased considerably over time when the solution contained oxalic acid. Si content increased to a specific degree over time when the solution contained no oxalic acid, but the Al content remained at a relatively low level (Fig. 5). This phenomenon proved that the presence of organic acids was favorable to dissolution of $\mathrm{Si}, \mathrm{Al}, \mathrm{K}, \mathrm{Na}, \mathrm{Ca}$, and other components into the solution. The feldspar dissolution in the solution without organic acid occurred along the reaction pathway of converting to new clay minerals and the undissolved $\mathrm{Al}$ crystallized into new minerals.

\section{(b)}

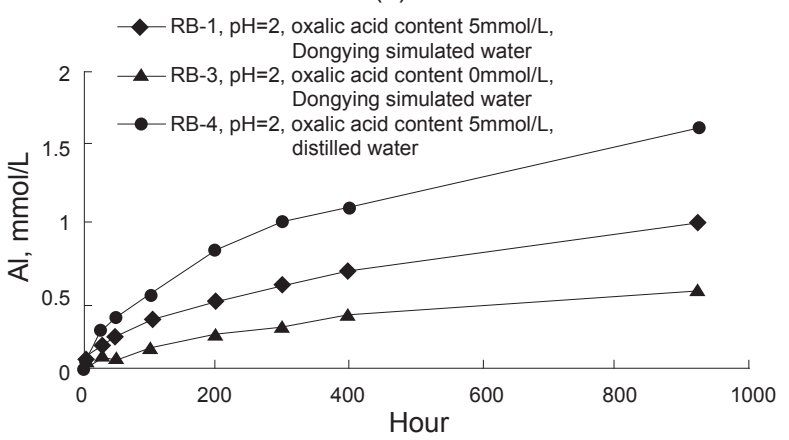

(d)

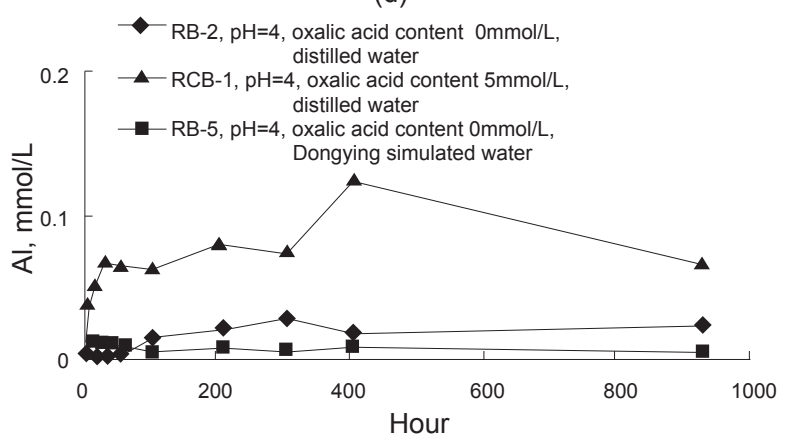

Fig. 5 Concentration change of $\mathrm{Si}$ and $\mathrm{Al}$ in solutions containing organic acid or not

\subsubsection{Influence of $\mathrm{pH}$ on feldspar dissolution}

Provided that the $\mathrm{pH}$ values were different while other conditions remained the same, the change of $\mathrm{Si}$ and $\mathrm{Al}$ contents in the water-rock interaction system demonstrated that $\mathrm{Si}$ and $\mathrm{Al}$ contents in the solution increased significantly with decreasing $\mathrm{pH}$ value, and the $\mathrm{Si} / \mathrm{A} 1$ ratio greatly decreased (Fig. 6). Decrease of $\mathrm{pH}$ value would enhance the complete decomposition of feldspar, while the increase of $\mathrm{pH}$ value would make feldspar convert into clay minerals.

The hydrocarbon generation process of organic matter is accompanied with the release of a large amount of organic acids into the water phase. When the water enters into the reservoir rocks, the contained organic acids could accelerate the complete decomposition of feldspar. Besides, it also helps to reduce the $\mathrm{pH}$ value of pore water in original reservoir rocks, which becomes an important factor for further dissolution of feldspar and the formation of secondary pores. 3.3.4 Influence of water salinity on feldspar dissolution

The impact of water salinity on feldspar dissolution is complex. In the condition of low $\mathrm{pH}$ value $(\mathrm{pH}=2)$, the $\mathrm{Si}$ and $\mathrm{Al}$ contents in the solution increased with the decrease of water salinity (Fig. 7(a) and (b)). At a high $\mathrm{pH}$ value $(\mathrm{pH}=4), \mathrm{Al}$ content in the solution increased and Si content decreased with the decrease of salinity (Fig. 7(c) and (d)). This demonstrated that the increase of water salinity was disadvantageous to the complete decomposition of feldspar, but advantageous to the formation of clay minerals. 
(a)

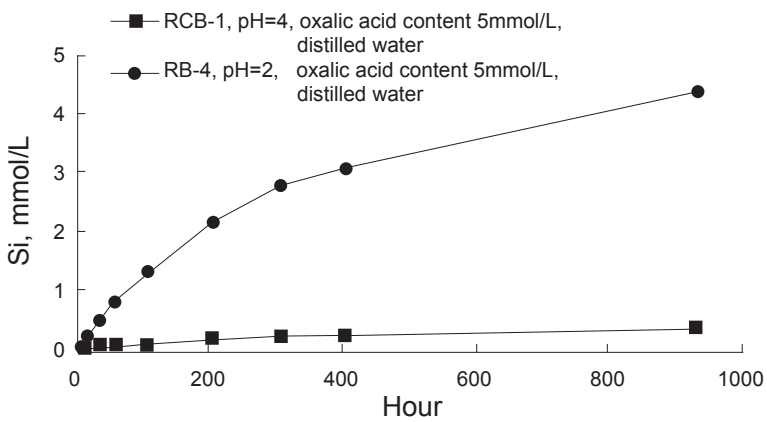

(c)

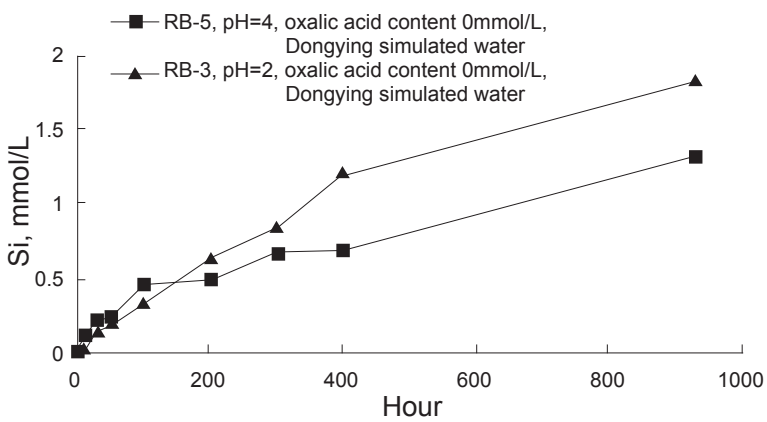

(b)

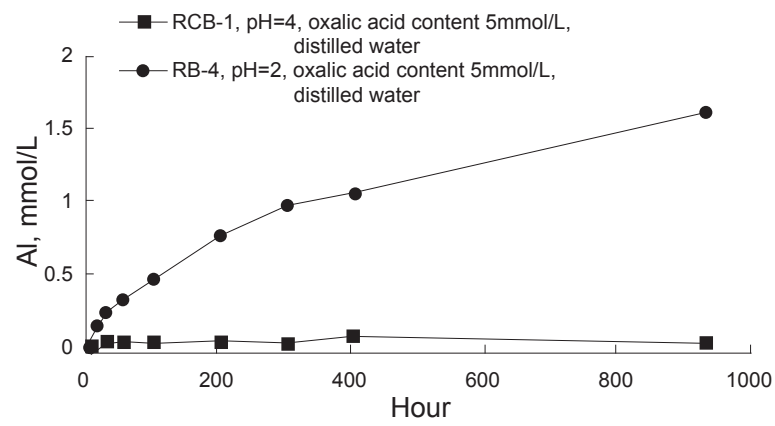

(d)

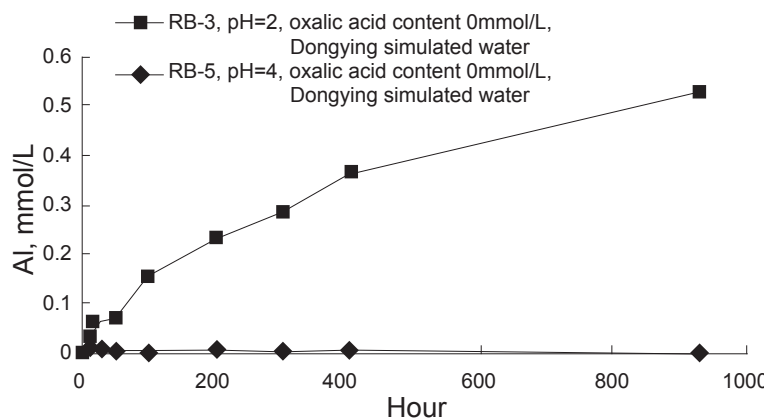

Fig. 6 Concentration change of Si and Al in distilled water and Dongying simulated water with different $\mathrm{pH}$ values

(a)

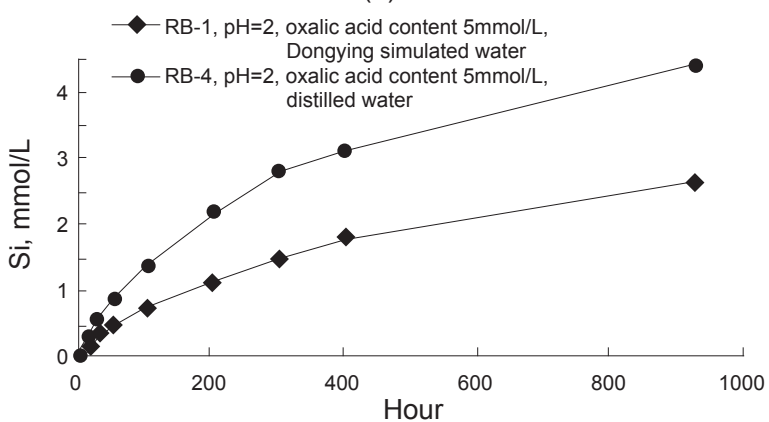

(c)

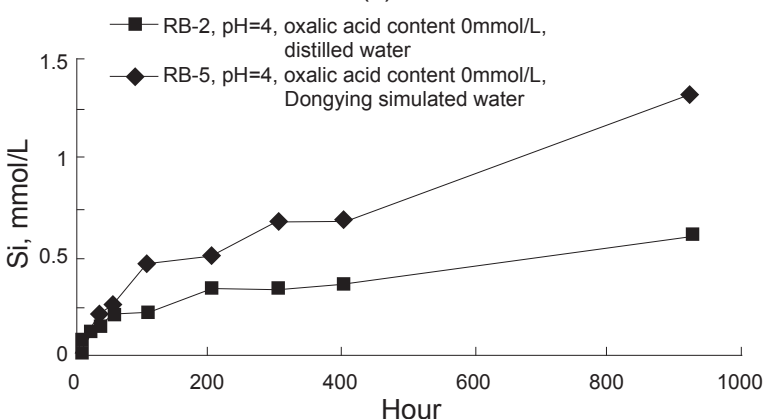

(b)

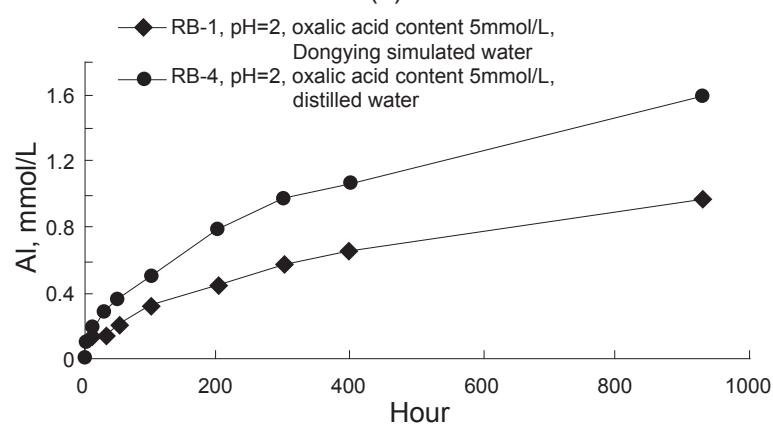

(d)

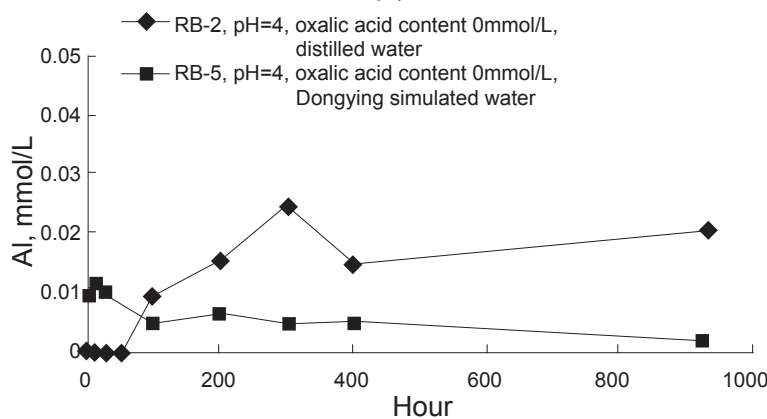

Fig. 7 Concentration change of $\mathrm{Si}$ and $\mathrm{Al}$ in solutions with different salinity at $\mathrm{pH}=2$ and $\mathrm{pH}=4$

The research of Megahan and Clayton (1986) showed that the lower the water salinity, the more easily the feldspar would dissolve. Blake and Walter (1996) held the opinion that the dissolution rate of orthoclase decreased with increasing salinity. The results of Blake and Walter (1999) supported the above opinion. Organic acid in the fluid, and decrease of $\mathrm{NaCl}$ enhanced dissolution of feldspar. Alkali cations such as $\mathrm{Na}^{+}$decreased the dissolution rate of feldspar in dilute acidic 
solutions by competing with protons for reactive exchange and adsorption sites on the feldspar surface, which can decrease the proton-promoted effect.

\section{Conclusions}

1) In the process of fluid-rock interaction, the solubility of carbonate minerals was higher than aluminosilicate minerals. The dissolution rate of albite was higher than that of $\mathrm{K}$-feldspar under acidic conditions, which is consistent with the simulated experimental results of feldspar single mineral.

2) The $\mathrm{pH}$ was the most important factor affecting the dissolution of mineral components. The lower the $\mathrm{pH}$ value of the fluid, the stronger the solubility of the mineral components. Under strongly acidic conditions, the difference in types of acidic medium only affected the dissolved amounts of various mineral components, and it did not have an obvious influence on the dissolution/precipitation trend. When the $\mathrm{pH}$ value was the same, oxalic acid had stronger dissolution ability for aluminosilicate minerals compared with hydrochloride acid. Hydrochloric acid had stronger dissolution ability for carbonate minerals. A higher temperature favored dissolution ability of oxalic acid for aluminosilicates but not for carbonates.

3) Experimental studies showed that an increase in temperature was favorable to feldspar dissolution. K-feldspar can form clay minerals, such as montmorillonite and kaolinite under acidic conditions. The decomposition intermediates of albite were distributed in kaolinite region, whether the temperature was high or low. The presence of organic acids was favorable to the dissolution of $\mathrm{Si}, \mathrm{Al}, \mathrm{K}$, and $\mathrm{Na}$ components of feldspar into the solution as ions, and the dissolution of feldspar without organic acids occurred along the reaction pathway of the formation of new clay minerals. The influence of water salinity on feldspar dissolution was rather complex. Generally speaking, increase of water salinity was favorable to the formation of clay minerals but unfavorable to the complete decomposition of feldspar.

\section{Acknowledgements}

This work was supported by China Postdoctoral Science Foundation-funded projects (No. 20070420492) and National Natural Science Foundation (No. 40772088).

\section{References}

Anjos S M C, De Ros L F, De Souza R S, et al. Depositional and diagenetic control on the reservoir quality of Lower Cretaceous Pendencia sandstones, Potiguar Rift Basin, Brazil. AAPG Bulletin. 2000. 84(11): 1719-1742

Blake R E and Walter L M. Effects of organic acids on the dissolution of orthoclase at $80^{\circ} \mathrm{C}$ and $\mathrm{pH}$ 6. Chemical Geology. 1996. 132(1-4): 91-102

Blake R E and Walter L M. Kinetics of feldspar and quartz dissolution at $70-80^{\circ} \mathrm{C}$ and near-neutral $\mathrm{pH}$ : effects of organic acids and $\mathrm{NaCl}$. Geochimica et Cosmochimica Acta. 1999. 63(13-14): 2043-2059
Brantley S L. Kinetics of dissolution and precipitation: experimental and field results. In: Proc. 7th Int. Symp.: Water-Rock Interaction (Edited by Welch S A and Ullman W J). Park City, US: A. A. Balkema. 1992. 3-6

Chardon E S, Livens F R and Vaughan D J. Reactions of feldspar surfaces with aqueous solutions. Earth-Science Reviews. 2006. 78(1-2): 1-26

Chen C P, Mei B W and Mao Z C. The initial experimental study for dissolving silicate mineral by dicarboxylic acid in aqueous systems. Journal of Mineralogy and Petrology. 1993. 13(1): 103-107 (in Chinese)

Chen L H, Zhao C L, Ji Y L, et al. Three formation mechanisms of secondary porosity in clastic gas reservoir rocks. Petroleum Exploration and Development. 1999. 26(5): 77-79 (in Chinese)

Dillon C G, Worden R H and Barclay S A. Simulations of the effects of diagenesis on the evolution of sandstone porosity. Journal of Sedimentary Research. 2004. 74(6): 877-888

Hellmann R. The albite-water system: Part I. The kinetics of dissolution as a function of $\mathrm{pH}$ at 100,200 , and $300^{\circ} \mathrm{C}$. Geochimica et Cosmochimica Acta. 1994. 58(2): 595-611

Huang S J, Yang J J, Zhang W Z, et al. Experimental study of feldspar dissolution by acetic acid at different burial temperatures. Acta Sedimentologica Sinica. 1995. 13(1): 7-16 (in Chinese)

Ji H C and Xu Z. Experimental simulation for dissolution in clastic reservoirs of the deep zone. Acta Geologica Sinica. 2007. 81(2): 212-219 (in Chinese)

Liu M H and Zhao C L. Diagenesis Evolutionary Model of Clastic Rocks. Dongying, Shandong: China University of Petroleum Press. 1993. 30-45 (in Chinese)

Li W G, Zhang X P and Zhong Y M. Formation mechanism of secondary dissolved pores in arcose. Oil and Gas Geology. 2005. 26(2): 220-229

Megahan W F and Clayton J L. Saturated hydraulic conductivities of granitic materials of the Idaho batholith. Journal of Hydrology. 1986. 84(1-2): 167-180

Oelkers E H and Schott J. Experimental study of anorthite dissolution and the relative mechanism of feldspar hydrolysis. Geochimica et Cosmochimica Acta. 1995. 59(24): 5039-5053

Qiu Y N, Xue S H and Ying F X. Continental Hydrocarbon Reservoirs in China. Beijing: Petroleum Industry Press. 1997. 147-217 (in Chinese)

Shah B A and Bandyopadhyay D N. Feldspar alteration and diagenetic characteristics of the Parsora sandstones, Son Basin, India. Gondwana Research. 2005. 8(2): 258-265

Shi J A, Jin H J and Xue L H. An analysis on mechanism of feldspar dissolution and its influence in feldspar-rich sandstone reservoir. Acta Sedimentologica Sinica. 1994. 12(3): 67-74 (in Chinese)

Wollast R and Chou L. Surface reactions during the early stages of weathering of albite. Geochimica et Cosmochimica Acta. 1992. 56(8): 3113-3121

Xiang T S, Cai C F and Fu H E. Dissolution of microcline by carboxylic acids at different temperatures and complexing reaction of $\mathrm{Al}$ anion with carboxylic acid in aqueous solution. Acta Sedimentologica Sinica. 2004. 22(4): 597-602 (in Chinese)

Xiao Y, Wang R C, Lu X C, et al. Experimental study on the lowtemperature dissolution of microperthite in alkaline solution. Acta Mineralogica Sinica. 2003. 23(4): 333-339 (in Chinese)

Yang J J, Huang Y M, Zhang W Z, et al. Experimental approach of dissolution of feldspar sandstone by acetic acid. Petroleum Exploration and Development. 1995. 22(4): 82-86 (in Chinese)

(Edited by Hao Jie) 